\title{
GENDER AND AGE GROUP STRUCTURES IN MUREŞ COUNTY, AT THE 2011 CENSUS
}

\author{
G. B. TOFAN'1, A. NIŢĂ², B. N. PĂCURAR ${ }^{3}$
}

\begin{abstract}
Gender and Age Group Structures in Mureş County, at the 2011 Census. The importance of possessing knowledge regarding the above mentioned component stems from territorial demographic and social-economic planning. Thusly, we emphasized the population gender structure, starting with both genders (BG), followed by male (M) and female (F) populations. We then proceeded to examine age groups, according to the logical succession comprising young people ( 0 -19 years of age), adults (20-59 years), and seniors ( $\geq 60$ years). The demographic pyramid of Mureş County reveals the same aging process recorded at national level, with a regressive population, where young people register increasingly lower values, while elderly people are more numerous. Age group structure is also influenced by other exogenous factors, such as migration (internal and external). The young urban population of Mureş County is lower $(19.89 \%)$ than in rural areas $(24.93 \%)$, while the latter areas have an older population $(23 \%)$ compared to urban areas $(21.72 \%)$. The adult population dominates all of the county's administrative-territorial units, the highest values having been recorded in urban settlements (58.39\%), where the county seat, the city of Târgu Mureș, reigns supreme (60.08\%), while rural areas registered an average of $52.09 \%$, with higher values (above $60 \%$ ) only in Corunca and Sângeorgiu de Mureş.
\end{abstract}

Keywords: population, male, female, age groups, 2011 Census.

1 „Vasile Goldiş” Western University of Arad, Faculty of Economic Sciences, Engineering and Informatics, Departament of Engineering and Informatics, Baia Mare Branch, 5 Culturii Street, Romania, e-mail: bogdan.tofan@uvvg.ro

2 „Babeș-Bolyai” University, Faculty of Geography, Gheorgheni Branch, Csiki Garden, Romania, e-mail: nitaadrian@hotmail.com

3 „Babeș-Bolyai” University Cluj-Napoca, Faculty of Geography, Centre for Research on Settlements and Urbanism; Cluj County Council, Urbanism and Territorial Planning Department, Cluj-Napoca, Romania, e-mail: pacurarbogdan@ymail.com 


\section{INTRODUCTION}

The authors of the study are at their third analysis of the gender and age structure of the population registered at the 2011 Census. The first study involved the County of Harghita, while the second Covasna County, both having been published in the Annals of Oradea University, Geography Series (XXVI, no. $1 \& 2 / 2016$ ) (see references).

We employed data from the Population and Household Census of 2011, the National Institute of Statistics enabling the possibility to freely access the necessary geodemographic indicators. We must also point out that the Mureş County Statistical Department (http://www.mures.insse.ro) is among the few in Romania which offers online data at microscalar level (component settlements and villages).

The second stage of the research involved the data analysis, processing and interpretation, in the form of tables, graphs and maps, thus insuring a proper dissemination of the results. We also used several scientific papers and studies that tackled this component (Pop et al., 1973; Surd, 2001; Pop, 2002; Pop et al., 2015; Tofan, 2014 b), focused either on the entire county (Şoneriu \& Mac, 1973) or on certain of its areas (Tofan, 2014 a), as well as the methodological guidebooks written by Vert in 1995 and 2001.

\section{THE GENDER AND AGE STRUCTURE OF THE POPULATION OF MUREŞ COUNTY}

At the census held on 20th October 2011, the County of Mureș registered 550,846 inhabitants, $48.82 \%(268,941$ people) being male, while $51.18 \%(281,905$ people) female.

\subsection{Both genders}

a) Young people (0-19 years), with a county percentage of $22.39 \%$ $(123,353$ inhabitants out of 550,846$)$, registered values around the above mentioned average, 21-23\%, in two urban areas (Târnăveni and Sovata) and in 21 communes (Adămuş, Ațintiş, Bogata, Breaza, Chețani, Corunca, Cuci, Fântânele, Găleşti, Găneşti, Hodoşa, Ibăneşti, Lunca, Măgherani, Pănet, Păsăreni, Răstolița, Ruşii Munţi, Sâncraiu de Mureş, Sânpetru de Câmpie and Vătava). 


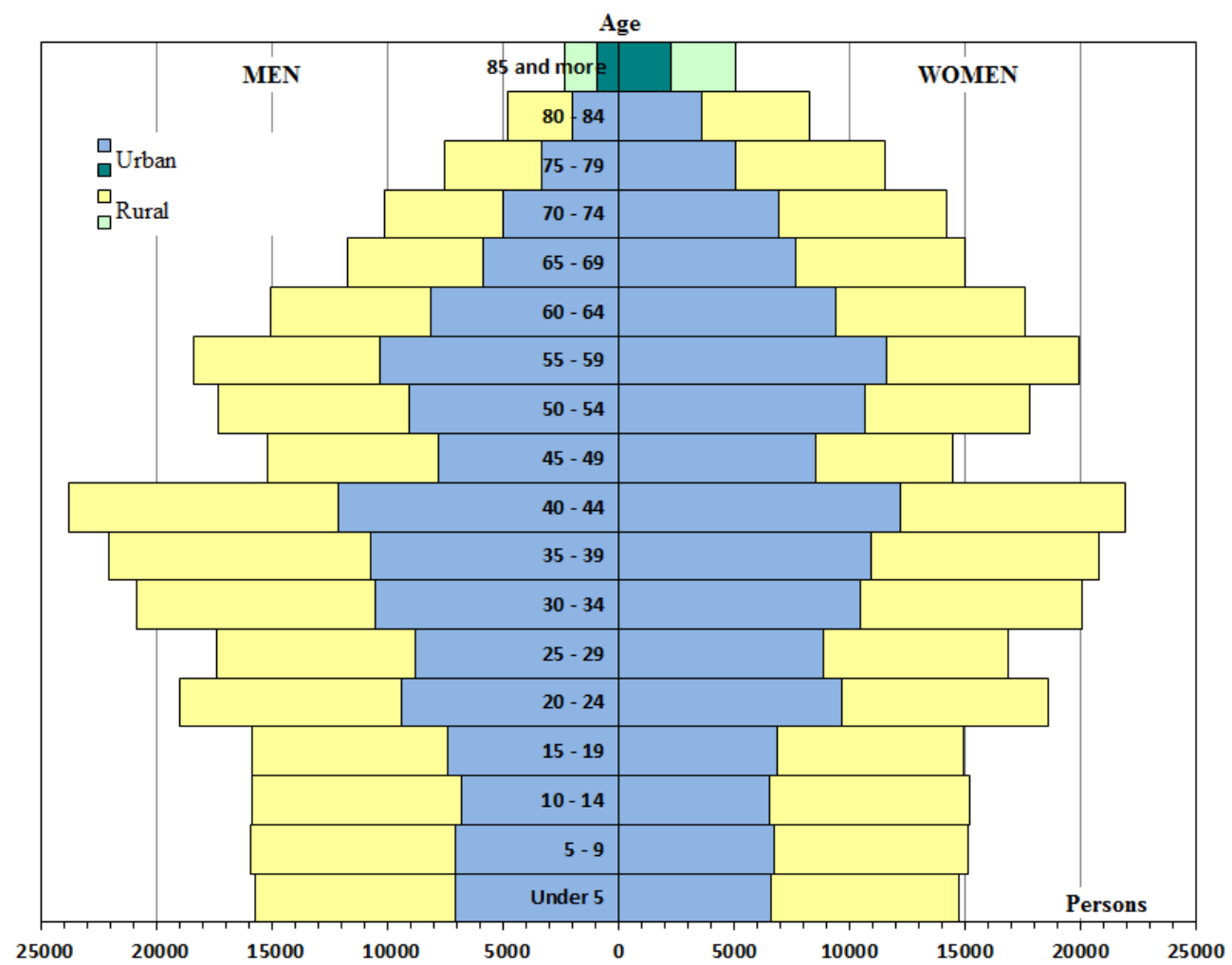

Fig. 1. The age pyramid of Mureș County, 2011

Values below 21\% were recorded in 15 administrative-territorial units, the commune of Băla having the lowest percentage (14.81\%). Higher values, $23-25 \%$, were found in 25 settlements ( 3 urban and 22 rural), while the highest, above 25\%, in the remaining 39 areas, such as Ungheni (25.79\%), Apold (31.71\%), Band (31.01\%, Nadeş (31.12\%), Ogra (31.13\%), Petelea (31.64\%), Vânători (32.25\%) and Viişoara (33.76\%).

b) Adults (20-59 years) registered an average of $55.25 \%$ (304,368 people) at county level. Values close to this number, $54-56 \%$, were found in 15 administrativeterritorial units (Târnăveni, Sângeorgiu de Pădure, Ungheni, Apold, Batoş, Brâncovenești, Ernei, Gănești, Gurghiu, Hodac, Ibănești, Livezeni, Lunca Bradului, Solovăstru, and Stânceni), while the next 13 units comprising the above 56\% category, where the highest value was found in Corunca (61.04\%). The lower category, below 54\%, encompass 74 areas, the lowest having been found in Băla (38.23\%) and Bichiş (37.89\%). 


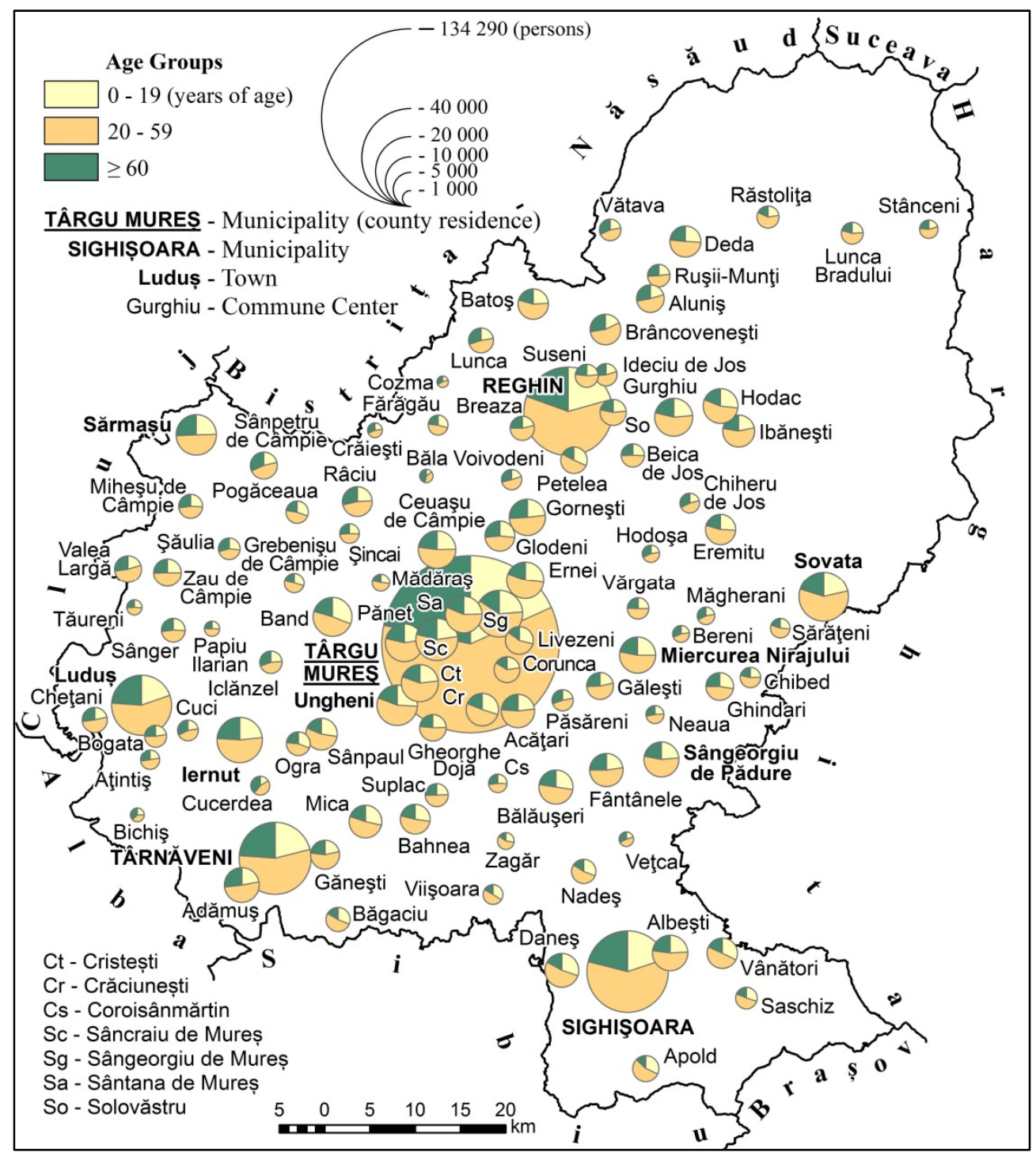

Fig. 2. Age group structure in Mureş County, LAU 2 level, at the 2011 Census

c) Elderly people (over 60 years of age) registered $22.35 \%$ at county level $(123,125$ people). The elderly population can be classified as follows: around the average, 21-23\%, values found in 17 settlements (Târgu Mureș, Sighişoara, Miercurea Nirajului, Sângeorgiu de Pădure, Albești, Bahnea, Bălăuşeri, Ceuaşu de 
Câmpie, Chibed, Grebenişu de Câmpie, Gurghiu, Ibăneşti, Mădăraş, Pănet, Pogăceaua, Sâncraiu de Mureş, and Solovăstru); the 23-25\% category including 13 units; above $25 \%$ in 44 areas, with its highest values of $46.96 \%$ found in Băla, and the category of below 21\% with the remaining 28 units (Apold having the lowest, $13.00 \%)$.

\subsection{The male population of Mureş County}

It ammounted to 268,941 people (48.82\%) and it also can be divided into three main age groups: young people, numbering 63,418 or $23.58 \%(0-19$ years); adults, with a number of 153,968 or $57.25 \%$ (20-59 years), and elderly with 51,555 people or a percentage of $19.17 \%$. In terms of the entire 102 administrativeterritorial units that comprise the county, the percentages of males were highly varied.

a) The young people group (0-19 years), with an average value of $23.58 \%$, registered percentages above the average, or $22-24 \%$, in three urban areas (Târnăveni, Sângeorgiu de Pădure, and Sovata) and 18 communes (Acățari, Adămuş, Aţintiş, Bogata, Breaza, Chiheru de Jos, Cozma, Cuci, Fântânele, Gălești, Gorneşti, Lunca, Măgherani, Pănet, Păsăreni, Sâncraiu de Mureș, Suplac, and Vătava). Values above $24 \%$ characterised 63 administrative-territorial units, such as the communes of Petelea (33.33\%) and Viişoara (33.84\%). Lower values, below 22\%, were found in the remaining 18 cities and communes of Mureş County, the lowest being recorded in Băla (15.84\%).

b) The adults age group (20-59 years) registered an average of $57.25 \%$ (153,968 inhabitants). Percentages around the average or $56-58 \%$ were recorded in four urban areas and 22 rural areas. Most units comprised the below 56\% category (61 to be more exact, Băla, with $42.86 \%$, having the lowest value), while the above $58 \%$ only included 15 settlements (Corunca, $61.87 \%$, had the highest percentage of males).

c) The elderly (above 60) reached an average of $19.17 \%$ (51,555 inhabitants out of a total of 268,941 males). 22 administrative-territorial units found themselves around the mentioned value, between 18-20\% (Târgu Mureş, Sighişoara, Miercurea Nirajului, Sângeorgiu de Pădure, Bălăuşeri, Beica de Jos, Breaza, Ceuaşu de Câmpie, Fântânele, Găneşti, Ghindari, Pogăceaua, Sâncraiu de Mureş, Şincai, Solovăstru and Suseni).

Values below 18\% were recorded in 32 units, the commune of Apold having the lowest percentage (11.68\%), while values above $20 \%$ were repoertd in the remaining 48 units, Băla again registering the lowest numbers $(41.30 \%)$. 


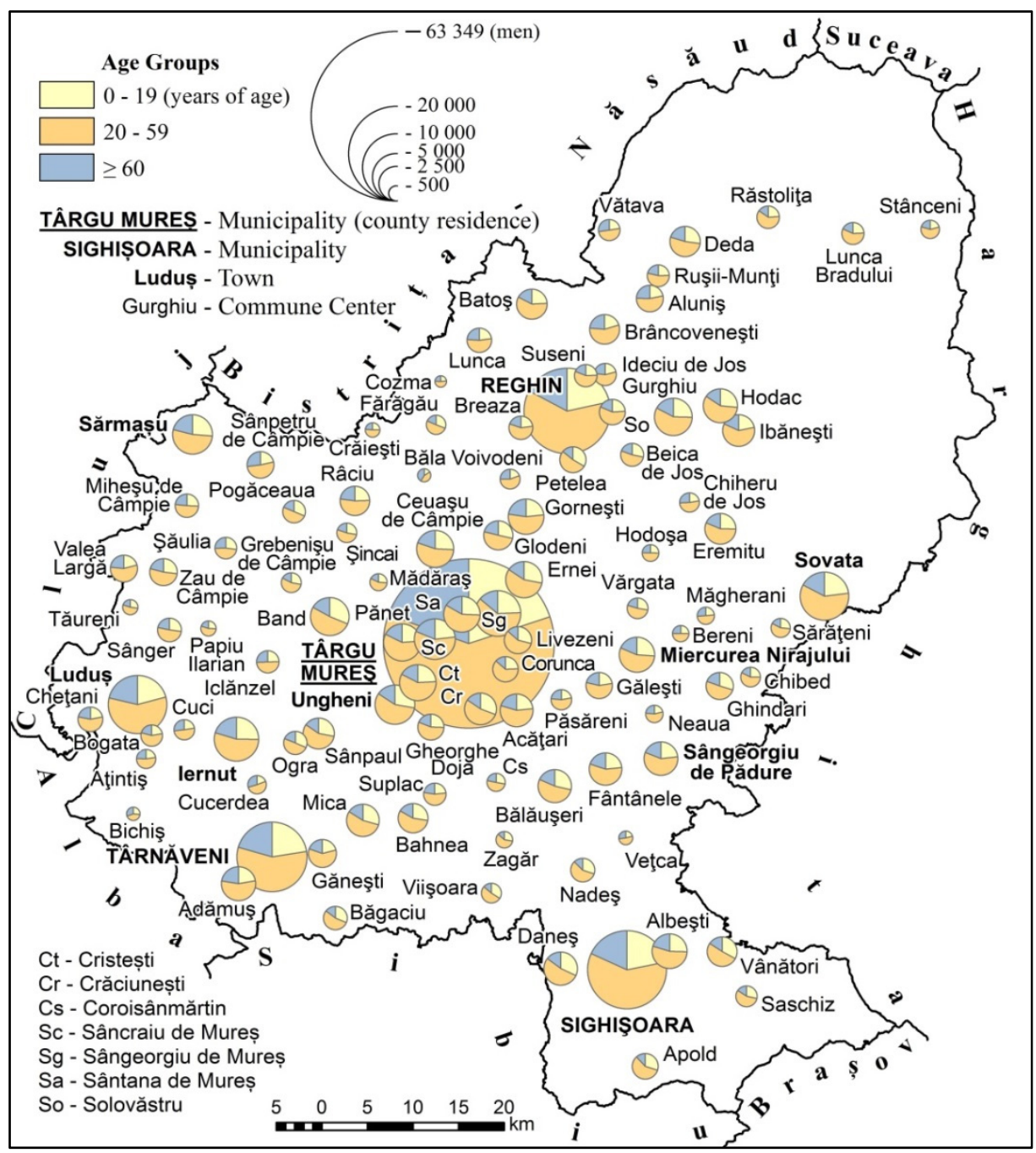

Fig. 3. The age group structure of the male population of Mureş County, LAU 2 level, at the 2011 Census

\subsection{The female population of Mureş County}

The female population of Mureș County numbered 281,905 individuals (51.18\%) of the county's population. Young females had a percentage of $21.26 \%$ (59,935 individuals), the adult 53.35\% (150,400 individuals), while the elderly $25.39 \%(71,570)$. 
a) The young category ( 0 -19 years), with an average percentage of $21.26 \%$, was classified as follows: the $20-22 \%$ category comprised 22 administrativeterritorial units; above $22 \%$ category included 64 areas (the highest value in Apold, 33.75\%); the below 20\% category in the remaining 6 urban areas and 10 communes (Cucerdea, 12.93\%, had the lowest representation of young females).

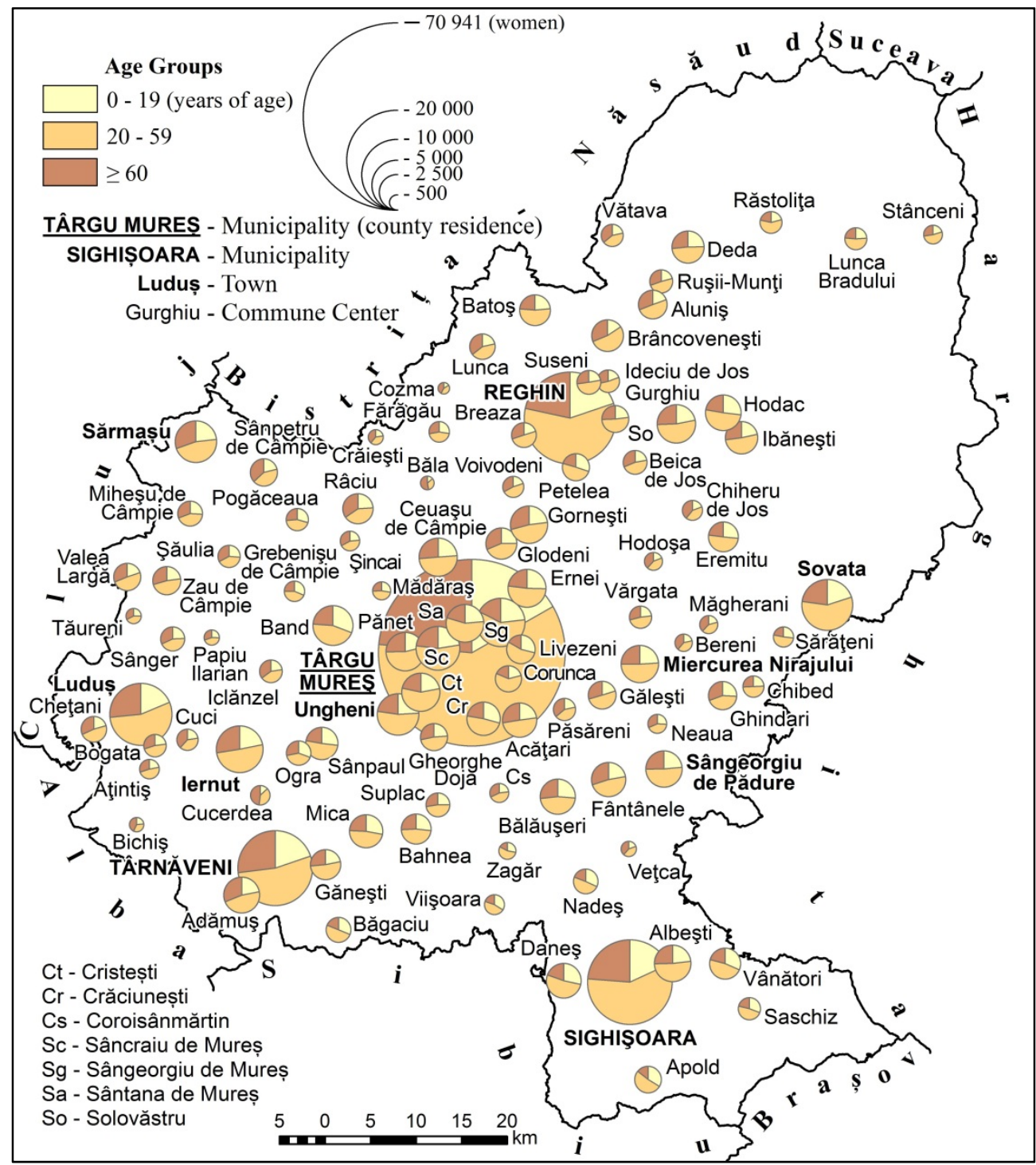

Fig. 4. The age group structure of the female population of Mureş County, LAU 2 level, at the 2011 Census 
b) The adult category (20-59 years), with 150,400 individuals (53.35\% of the total female population of the county) was distributed in the following manner: values of $52-54 \%$ in eight settlements (Târnăveni, Ungheni, Batoş, Brâncovenești, Daneș, Gurghiu, Lunca Bradului, and Pănet), above 54\% with 13 areas (Târgu Mureș, Reghin, Sighişoara, Luduș, Sovata, Corunca (the highest value, 60.20\%), Cristești, Livezeni, Răstolița, Sâncraiu de Mureș, Sângeorgiu de Mureș, Sântana de Mureș and Zagăr; values below 52\% in most administrativeterritorial units (81), Băla registering the lowest percentage, $33.42 \%$.

c) The elderly female category (over 60 years), with an average of $25.39 \%$ (71,570 individuals out of a total of 281,905 women) had the following structure: 11 areas recorded values around the average, 24-26\%, - Miercurea Nirajului, Sângeorgiu de Pădure, Albești, Bahnea, Chibed, Grebenişu de Câmpie, Gurghiu, Mădăraş, Mica, Pănet and Solovăstru. Values below 24\% were found in 30 units (the commune of Apold having the lowest value, 14.34\%), while values above $26 \%$ were registered in 61 towns and communes, Băla having the highest rate of elderly women in the county (52.83\%).

\section{CONCLUSIONS}

At county level, out of a total population of 550,846 inhabitants, females formed the majority (a ratio of 104 women / 100 men). We encountered the following situation after analysing the major age groups of Mureş County: $55.25 \%$ adults (304,368 people out of 550,846 inhabiting the county), $22.35 \%$ elderly $(123,125)$ and $22.39 \%$ young people.

Table 1. The gender and age group structure of Mureş County at the 2011 Census

(Data source: 2011 Census)

\begin{tabular}{|c|c|c|c|c|c|c|c|c|}
\hline \multirow{2}{*}{$\begin{array}{l}\text { Mureş } \\
\text { County }\end{array}$} & \multirow{2}{*}{ Gender } & \multirow{2}{*}{$\begin{array}{l}\text { Total stable } \\
\text { population }\end{array}$} & \multicolumn{6}{|c|}{ Age groups } \\
\hline & & & $0-19$ & $\%$ & $20-59$ & $\%$ & $\geq 60$ & $\%$ \\
\hline \multirow{3}{*}{ TOTAL } & BG & 550846 & 123353 & 22.39 & 304368 & 55.25 & 123125 & 22.35 \\
\hline & $\mathbf{M}$ & 268941 & 63418 & 23.58 & 153968 & 57.25 & 51555 & 19.17 \\
\hline & $\mathbf{F}$ & 281905 & 59935 & 21.26 & 150400 & 53.35 & 71570 & 25.39 \\
\hline \multirow{3}{*}{ Urban } & BG & 276773 & 55039 & 19.89 & 161613 & 58.39 & 60121 & 21.72 \\
\hline & M & 132494 & 28360 & 21.40 & 78801 & 59.48 & 25333 & 19.12 \\
\hline & $\mathbf{F}$ & 144279 & 26679 & 18.49 & 82812 & 57.40 & 34788 & 24.11 \\
\hline \multirow{3}{*}{ Rural } & BG & 274073 & 68314 & 24.93 & 142755 & 52.09 & 63004 & 22.99 \\
\hline & M & 136447 & 35058 & 25.69 & 75167 & 55.09 & 26222 & 19.22 \\
\hline & $F$ & 137626 & 33256 & 24.16 & 67588 & 49.11 & 36782 & 26.73 \\
\hline
\end{tabular}

$\mathrm{BG}=$ both genders, $\mathrm{M}=$ male, $\mathrm{F}=$ female . 
Young people (22.39\%) varied in terms of percentages between $14.81 \%$ (Băla) and 33.76\% (Viişoara), values above 30\% having been found only in Crăciuneşti, Daneş, Pogăceaua, Band, Băgaciu, Apold, Nadeş, Ogra and Petelea.

Adults were the most abundant (55.25\%), values above $60 \%$ having been found in the county residence city of Târgu-Mureș (60.08\%) and in two adjacent communes (Sângeorgiu de Mureș, 60.38\%, and Corunca, 61.04\%), while the lowest values were recorded in two rural settlements with populations below 1,000 inhabitants (Bichiş, 37.89\% and Băla, 38.23\%).

Older people averaged $22.35 \%$, while the highest percentage of elderly (46.96\%) was registered in Băla, and the lowest in Apold, a rural community where the Gypsy population exceeds $20 \%$.

In urban areas, values below the $21.72 \%$ average were recorded in half of the county's towns (Ungheni, Reghin, Sovata, Sighişoara and Târgu-Mureş), areas where adults were numerous. The town of Sărmaşu $(25.80 \%)$ was at the opposite side, recording the highest value.

\section{REFERENCES}

1. Pop Gr., Galoş M., Ivan Ana, Moș Tr. (1973). Structura pe grupe de vârstă a populaţiei judeţului Bihor, Lucrări Ştiinţifice, Seria Geografie, Oradea.

2. Pop P. Gr. (2002). Structura pe sexe a populaţiei Regiunii de Nord-Vest a României, Studia UBB Geographia, 2, Cluj-Napoca.

3. Pop P. Gr., Zotic V., Alexandru Diana Elena (2015). The Romanian Population by Gender and Age Groups in 2011, Studia UBB Geographia, LX, 1, Cluj-Napoca.

4. Surd, V. (2001). Geodemografie, Edit. Presa Universitară Clujeană, Cluj-Napoca.

5. Şoneriu I., Mac I. (1973). Judeţul Mureş, Edit. Academiei R.S.R, Bucuresti.

6. Tofan G.B. (2014 a). Defileul Mureşului. Studiu de Geografie Umană, Edit. Presa Universitară Clujeană, Cluj-Napoca.

7. Tofan, G.B. (2014 b). The Ethnic and Confessional Structure of Mureş County in 2011, Analele Univ. din Oradea, Seria Geografie, Tom XXIV, Nr. 1, Edit. Universității din Oradea.

8. Tofan, G.B., Niță, A., Păcurar, B.N. (2016). Gender and Age Group Structure in Harghita County, at the 2011 Census, Analele Univ. din Oradea, Seria Geografie, Tom XXVI, Nr. 1, Edit. Universității din Oradea, Oradea.

9. Tofan, G.B., Niță, A., Păcurar, B.N. (2016). Gender and Age Group Structure in Covasna County, at the 2011 Census, Analele Univ. din Oradea, Seria Geografie, Tom XXVI, Nr. 2, Edit. Universității din Oradea, Oradea.

10. Vert, C. (1995). Analiza geodemografică. Manual practic, Universitatea de Vest din Timişoara, Facultatea de Chimie-Biologie-Geografie, Catedra de Geografie, Timişoara.

11. Vert, C. (2001). Geografia populaţiei. Teorie şi metodologie, Edit. Mirton, Timişoara. 
12. *** (1984). Geografia României, II, Geografia Umană și Economică, Edit. Academiei R. S. România, Bucuresti.

13. *** (2012). Reactualizarea Planului de amenajare a teritoriului județean, judeţul Mureş, partea I, Analiza situaţiei existente, vol. IV, Structura socio-demografică, Populaţia şi potenţialul demografic, proiectant: Universitatea „Babeș-Bolyai” Cluj-Napoca, Facultatea de Geografie, Cluj-Napoca.

14. http://www.recensamantromania.ro/rezultate-2, consulted at 01 April 2016.

15. http://www.mures.insse.ro/main.php, consulted at 01 April 2016. 